\title{
Identification of a Common Mutation in Finnish Patients with Nonketotic Hyperglycinemia
}

\author{
Shigeo Kure, * Masaru Takayanagi, * Kuniaki Narisawa, * Keiya Tada, ${ }^{\star}$ and Jaakko Leisti ${ }^{\star}$ \\ *Departments of Biochemical Genetics and ${ }^{\ddagger}$ Pediatrics, Tohoku University School of Medicine, 1-1 Seiryo-machi, Aoba-ku, Sendai 980, \\ Japan; and ${ }^{\S}$ Department of Clinical Genetics, Oulu University Central Hospital, SF-90220, Oulu, Finland
}

\begin{abstract}
Nonketotic hyperglycinemia (NKH) is an autosomal recessive metabolic disorder caused by the defects in the glycine cleavage system (GCS; EC 2.1.2.10), a multienzyme system that consists of four individual components. NKH is a rare disorder in many countries, but with a very high incidence in northern Finland. To understand the genetic background of this high incidence, we examined the GCS in a typical case of NKH at the molecular level. The activity of $P$ protein, a component of the GCS, was not detected in the lymphoblasts of the patient, while $P$ protein mRNA of a normal size and level was present in the cells. Structural analysis of $P$ protein $m R N A$ from the patient revealed a single nucleotide substitution from $G$ to $T$ in the protein coding region, which resulted in an amino acid alteration from Ser Se4 $^{56}$ to $\mathrm{Il}^{564}$. No P protein activity was detected when the mutant $P$ protein with this amino acid substitution was expressed in COS 7 cells. The patient was homozygous for this mutation. Furthermore, this mutation was present in $\mathbf{7 0 \%}$ (14 of 20) of $P$ protein gene alleles in Finnish patients with NKH, whereas it was not found in 20 alleles of non-Finnish patients. The results suggest that this mutation is responsible for the high incidence of NKH in Finland. (J. Clin. Invest. 1992. 90:160-164.) Key words: glycine cleavage system • P protein gene $\bullet$ Finland $\bullet$ point mutation $\bullet$ expression study
\end{abstract}

\section{Introduction}

Nonketotic hyperglycinemia $(\mathrm{NKH})^{1}$ is an autosomal recessive disorder characterized by abnormally high concentrations of glycine in the plasma and cerebrospinal fluid in the absence of excess organic acids (1). The fundamental defect lies in the mitochondrial glycine cleavage system ([GCS; EC2.1.2.10]) (2), a multienzyme system that consists of four individual proteins referred to as $\mathrm{P}, \mathrm{H}, \mathrm{T}$, and $\mathrm{L}$ proteins (3). Previous studies revealed that most patients with NKH have a defect in $P$ protein (4), a pyridoxal phosphate-dependent glycine decarboxylase with two identical subunits. The recent cloning and se-

Address correspondence to Dr. Shigeo Kure, Department of Biochemical Genetics, Tohoku University School of Medicine, 1-1 Seiryo-machi, Aoba-ku, Sendai, 980 Japan.

Received for publication 2 October 1991 and in revised form 14 January 1992.

1. Abbreviations used in this paper: ASO, allele-specific oligonucleotide; GCS, glycine cleavage system; NKH, nonketotic hyperglycinemia; OAT, ornithine- $\delta$-aminotransferase.

J. Clin. Invest.

(c) The American Society for Clinical Investigation, Inc. 0021-9738/92/07/0160/05 \$2.00

Volume 90 , July 1992, 160-164 quencing of the cDNA encoding the human $\mathrm{P}$ protein subunit precursor provided the necessary molecular framework for direct investigation of the molecular defects responsible for $\mathrm{NKH}$ $(5,6)$.

$\mathrm{NKH}$ is a rare disorder in many countries, whereas the incidence of $\mathrm{NKH}$ is very high in northern Finland $(1: 12,000$ births) (7). Because of the national and regional isolation of the Finnish population, there are about 30 monogenic disorders that are either unique to, or appear at, a high frequency in Finland; these disorders, including NKH, are designated "Finnish genetic diseases" $(8,9)$. Clinically, NKH is a serious disease with no effective therapy and a high neonatal mortality rate. Those surviving have been severely mentally retarded and suffered from intractable seizures. Despite the genetic and clinical importance of NKH in Finland, the molecular defect in Finnish patients is unknown. In fact, which component of GCS is defective in Finnish patients has not been reported.

The main purpose of this study was to identify a common molecular defect among NKH patients in Finland, which might provide information about the genetic structure of Finnish population. Another purpose of this investigation is to establish an experimental paradigm for the direct investigation for the mutations in patients with NKH. Because the GCS is expressed specifically in mitochondria of the liver, kidney, and brain, it was previously impossible to analyze the enzyme activity and the expression of mRNA without those tissues (10). In this study, we used the EBV-transformed lymphoblasts as a source of the enzyme proteins and mRNAs of the GCS components. This approach is based on our recent observation that a small amount of the GCS is expressed in lymphoblasts (11), and allows examination of mutant GCS components and mRNAs with blood samples.

\section{Methods}

The patients with NKH. 10 unrelated Finnish patients (1-10) were clinically and biochemically diagnosed as having the neonatal type of NKH at Oulu University Central Hospital. We established a lymphoblast cell line from a patient (patient 1) with the typical clinical course using EBVirus. The genomic DNA samples of the 10 patients were obtained by extraction from either paraffin-enblocked samples (12) or blood-blotted papers (13). DNA from non-Finnish patients with NKH (three Japanese and seven Caucasians, including one Swede) was extracted from leukocytes or fibroblasts.

Enzyme analysis of the glycine cleavage system. The overall activity of the GCS in lymphoblasts was determined by the decarboxylation assay of $\left[1-{ }^{14} \mathrm{C}\right]$ glycine $(11,14)$. The activities of $\mathrm{P}$ and $\mathrm{H}$ protein were measured by the exchange reaction between glycine and $\mathrm{NaH}^{14} \mathrm{CO}_{3}$ $(11,15)$. The activity of $\mathrm{T}$ protein was determined by the glycine synthesis reaction (16) in the presence of an excess amount of $P, H$, and lipoamide dehydrogenase (Boehringer Mannheim Biochemicals, Indianapolis, IN). $\left[1-{ }^{14} \mathrm{C}\right]$ Glycine and $\mathrm{NaH}^{14} \mathrm{CO}_{3}$ were purchased from Amersham Corp. (Arlington Heights, IL). Protein concentration was 
determined by the method of Bradford (17) with a kit from Bio-Rad Laboratories, Richmond, CA.

RNA blot analysis. Total RNAs were extracted from the lymphoblasts of patient 1 and a normal control by the method of Chomczynski (18). Poly $\left(\mathrm{A}^{+}\right)$RNA fractions were purified with an mRNA Purification Kit (Pharmacia-LKB, Uppsala, Sweden). $5 \mu \mathrm{g}$ of poly $\left(\mathrm{A}^{+}\right) \mathrm{RNA}$ were subjected to formaldehyde gel electrophoresis. After electrophoresis, the RNAs were transferred to a Hybond-N nylon membrane (Amersham Corp.) by the capillary method, and hybridized with the ${ }^{32}$ P-labeled human $\mathrm{P}$ protein cDNA, pP12-1 (5). To determine the level of P protein mRNA, the level of human $\beta$-actin mRNA ( $2.1 \mathrm{~kb}$ in length) in the same blot was used as an internal standard. Radioactivity of signals was determined by the Bio-Image analyzer BAS 2,000 (Fiji Film, Kanagawa, Japan).

Sequencing analysis of $P$ protein $c D N A$. The method of reverse transcription from poly $\left(\mathrm{A}^{+}\right) \mathrm{RNA}$ and $\mathrm{PCR}$ amplification of $\mathrm{P}$ protein cDNA has been previously described (5). The amplified 5 '-half and 3 '-half of the $P$ protein cDNA fragments were subcloned into the expression vector pEUK-C1 (Clonetech Laboratories, Inc., Palo Alto, CA). The sequence of the cloned $P$ protein CDNA was determined by the dideoxy-termination method with 15 internal primers. We used either an automated A.L.F. DNA sequencer (Pharmacia-LKB) or a manual method with ${ }^{35} \mathrm{~S}-\alpha$-dCTP (Amersham Corp.) and a Sequenase sequencing kit (version 2.0, 7-deaza-dGTP edition; United States Biochemical Corp, Cleveland, $\mathrm{OH}$ ). Direct sequencing of the amplified PCR products (19) was also used to clarify the ambiguous nucleotides in the sequence analysis of the P protein cDNA clones.

Expression analysis of mutant $P$ protein $c D N A$. The strategy for the expression of the mutant $P$ protein cDNA was essentially the same as that of the previous report (5). Briefly, the chimeric $P$ protein cDNA, which had the normal 5'-half and mutant 3 '-half of $P$ protein $\mathrm{CDNA}$, was ligated with pEUK-Cl at XbaI and BamHI sites. The expression vector that contained the normal $P$ protein cDNA was similarly constructed. The expression vectors with normal and mutant $\mathbf{P}$ protein cDNA were designated as pEUK-P(N) and pEUK-P(S564I), respectively. $20 \mu \mathrm{g}$ of each expression vector, wild-type pEUK-C1, pEUK$P(N)$, and pEUK-P(S564I), was transfected into the COS 7 cells, which were subconfluently cultured in $60 \mathrm{~mm}$ dishes using the Lipofectin reagent (Gibco Laboratories, Grand Island, NY), according to the manufacturer's manual. After a 48-h incubation period, the cells were harvested and stored at $-80^{\circ} \mathrm{C}$ until analysis. The cell pellets were thawed and lysed in $400 \mu \mathrm{l}$ of $20 \mathrm{mM}$ potassium phosphate buffer $(\mathrm{pH}$ $7.0), 1 \mathrm{mM}$ dithiothreitol, $0.1 \mathrm{mM}$ pyridoxal phosphate, $2 \mu \mathrm{g} / \mathrm{ml}$ of leupeptin, and $2 \mu \mathrm{g} / \mathrm{ml}$ of pepstatin $\mathrm{A}$. The extracts were sonicated and subsequently centrifuged at $15,000 \mathrm{~g}$ for $30 \mathrm{~min}$ at $4^{\circ} \mathrm{C}$. The superna$\operatorname{tant}(300 \mu \mathrm{l})$ of each extract was used for the P protein assay.

Allele-specific oligonucleotide (ASO) hybridization. The genomic DNA fragment containing the S564I mutation site was amplified by PCR with a set of primers; 5'-dGTCTCTTGGTCCTACCTAATA ( 21 mer) and 5'-dGTCACAAGATCGAAGTGGATT (21 mer). Both primers were located in introns that were 5'-and 3'-adjacent to the exon in which the mutation site resided. The thermoprofile of the polymerase chain reaction (PCR) amplification was 30 cycles of $94^{\circ} \mathrm{C}$ for 1 min, $55^{\circ} \mathrm{C}$ for $1 \mathrm{~min}$, and $72^{\circ} \mathrm{C}$ for $1 \mathrm{~min}$. The PCR products $(230 \mathrm{bp}$ in length) from a normal control, patient 1 , and his parents were subjected to electrophoresis on an agarose gel $(4 \times 11 \mathrm{~cm})$ and transferred onto a GeneScreen Plus nylon membrane (New England Nuclear, Boston, MA) by the alkaline transfer method (20). The ASO detection probes for the normal allele and the mutant allele were 5'-dACTTGAACAGTTCGTCTG (17 mer) and 5'-dACTTGAACATTTCGTCTG ( $17 \mathrm{mer})$, respectively. The underlined nucleotides are located at the S564I mutation site. The primers were ${ }^{32} \mathrm{P}$-labeled with T4 polynucleotide kinase (TOYOBO, Tokyo, Japan) and [ $\gamma^{32}$ P]ATP (Amersham Corp.).

The modified PCR for the detection of S564I mutation. The basic mechanism of this method is illustrated in Fig. 5. The forward and reverse primers used here were 5'-dGGATCCTGCACCATGAAACTG-AATA (25 mer) and 5'-dGCTACTTACTGCGAGTTCAGA-
CGTA ( 25 mer), respectively. The first 9-nucleotide sequence in the reverse primer was taken from the sequence of the adjacent intron. The underlined nucleotide in the forward primer was altered from $A$ to $T$ in order to generate the recognition site for SspI in the PCR products amplified from the mutant allele. Similarly, the $C$ nucleotide in the reverse primer was replaced by the underlined $T$ to make the recognition site for RsaI in PCR product amplified from the normal allele. The amplification required denaturation at $94^{\circ} \mathrm{C}$ for $1 \mathrm{~min}$, followed by an annealing and extension step at $65^{\circ} \mathrm{C}$ for $1 \mathrm{~min}$. This cycle was repeated 30 times. The restriction enzyme digestion with Rsal or SspI was performed in a total $20-\mu$ l system which contained $10 \mu \mathrm{l}$ of PCR products, $10 \mathrm{U}$ of Rsal (TOYOBO) or SspI (New England Biolabs, Beverly, MA), and $2 \mu$ lof $10 \times$ digestion buffers supplemented by the manufacturers. The digests were subjected to electrophoresis on a $5.5 \%$ agarose gel that contained 4\% NuSieve GTG agarose (FMC Corp., Rockland, ME) and 1.5\% SeaKem ME agarose (FMC Corp.). The size-separated DNA bands were stained with ethidium bromide and visualized with an ultraviolet transilluminator.

\section{Results}

Identification of the mutation in patient 1 . The overall activity of the GCS and each component of the GCS were determined in the lymphoblast cells established from patient 1 . The overall activity and $P$ protein activity were not detected, whereas the activity of the other enzyme components were within the normal range ( Table $I$ ), indicating that patient 1 had a defect in $P$ protein.

RNA blot analysis revealed that $P$ protein mRNA expressed in the lymphoblasts of patient 1 could not be distinguished from that of the normal control in terms of size (Fig. 1). The level of the mRNA was 1.7-fold more than that of the normal control, while the level of the $\beta$-actin mRNA, which was used as an internal standard, was 1.5 times more than the normal control. Therefore, the ratio of patient and control $\mathbf{P}$ protein mRNA level was estimated as $1.1(1.7 / 1.5)$, indicating that the level of $P$ protein mRNA was not reduced from the level of the normal control.

Analysis of the cDNA encoding the $P$ protein identified a $G$ to $T$ replacement at nucleotide 1,691 (for the nucleotide number, see reference 5). This mutation resulted in the substitution of an isoleucine (codon ATT) for serine (codon AGT) at amino acid residue 564 of the P protein precursor subunit (Fig. 2 ). Using the single letter code for amino acids, we designated this nucleotide change as the S564I mutation. Other nucleotide replacements observed were either silent mutations ( $\mathrm{T}$ to $\mathrm{A}$ at 90, $\mathrm{C}$ to $\mathrm{T}$ at 2,211, $\mathrm{C}$ to $\mathrm{T}$ at 2,271, and $\mathrm{T}$ to $\mathrm{C}$ at 2,496) not altering amino acids or the errors caused by Taq DNA polymerase ( $T$ to $G$ at 1,323, $A$ to $C$ at 1,484 , and $T$ to $G$ at 1,582). The nucleotide changes due to the errors of Taq DNA polymerase were verified by direct sequencing of the PCR products.

Table I. The Enzymatic Analysis of the GCS in Lymphoblasts Established from Patient 1

\begin{tabular}{llccc}
\hline & \multicolumn{4}{c}{ Enzyme activity } \\
\cline { 2 - 5 } Lymphoblasts & Overall & P protein & H protein & T protein \\
\hline & \multicolumn{4}{c}{ nmol of product formed/h per $m g$} \\
Control & 1.1 & 0.9 & 0.5 & 1.4 \\
Patient 1 & 0 & 0 & 0.8 & 1.1 \\
& & &
\end{tabular}




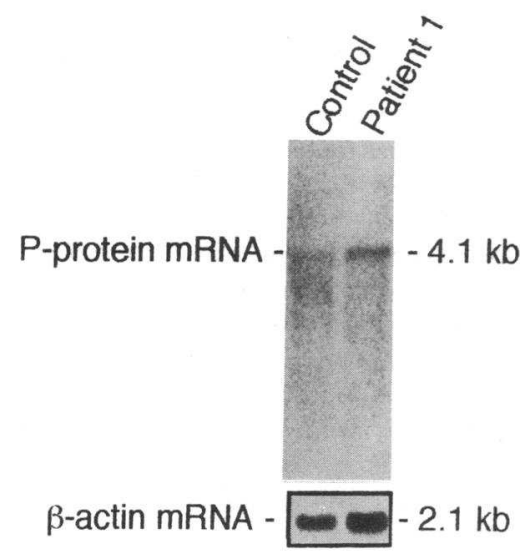

Figure 1. RNA blot analysis of $\mathrm{P}$ protein mRNA. The upper autoradiogram shows the hybridization pattern of $P$ protein mRNA. The RNA blotted filter was rehybridized with human $\beta$-actin cDNA, which was used as an internal standard to estimate the level of $P$ protein mRNA. $5 \mu \mathrm{m}$ of poly $\left(\mathrm{A}^{+}\right)$RNA purified from the lymphoblasts of a control and the patient 1 were subjected to each lane.

To examine whether this mutation was a cause of $\mathrm{NKH}$, we designed an expression experiment to synthesize the mutant $P$ protein polypeptide in $\operatorname{COS} 7$ cells (Fig. 3 ). When the normal $P$ protein cDNA was expressed in COS 7 cells, the specific activity of $P$ protein in the cell extract was $8.7 \pm 1.4 \mathrm{nmol}$ of glycine formed per hour per milligram protein, which was almost equivalent to the value in human liver (21). The value was 0.3 \pm 0.1 when the mutant $P$ protein cDNA was expressed in COS 7 cells. This value was similar to the specific activity of the endogenous $P$ protein in COS 7 cells $(0.2 \pm 0.2)$.

Analysis of genotype in the NKH family. The genomic DNA fragment containing the S564I mutation site was amplified by PCR. The amplified DNA fragments from patient 1 and his parents were analyzed by ASO probe hybridization. The DNA fragments from his parents hybridized with both the normal and mutant probes, whereas those from patient 1 hybridized only with the mutant probe (Fig. $4 \mathrm{~A}$ ). Therefore, the parents and patient 1 were heterozygous and homozygous for the S564I mutation, respectively.

We developed a modified PCR method to detect the S564I mutation rapidly and easily (Fig. 5). One nucleotide in each forward and reverse primer was modified to produce recognition sites for the restriction enzymes in the PCR products. The digestion patterns of the PCR products amplified from the genomic DNAs of the patient and his parents are shown in Fig. $4 B$. The result was consistent with that of the ASO hybridization as described above.

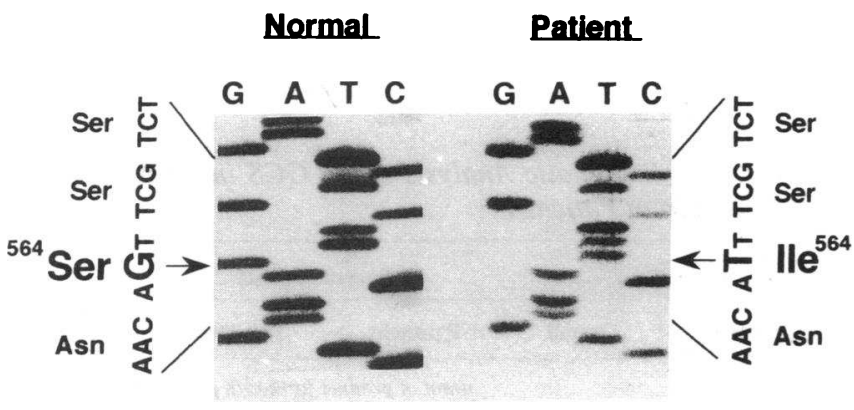

Figure 2. Sequence analysis of a point mutation in $\mathrm{P}$ protein cDNA. The autoradiogram shows the nucleotide change from $G$ to $T$, which resulted in the amino acid substitution from $\mathrm{Ser}^{564}$ to $\mathrm{Ile}^{564}$.

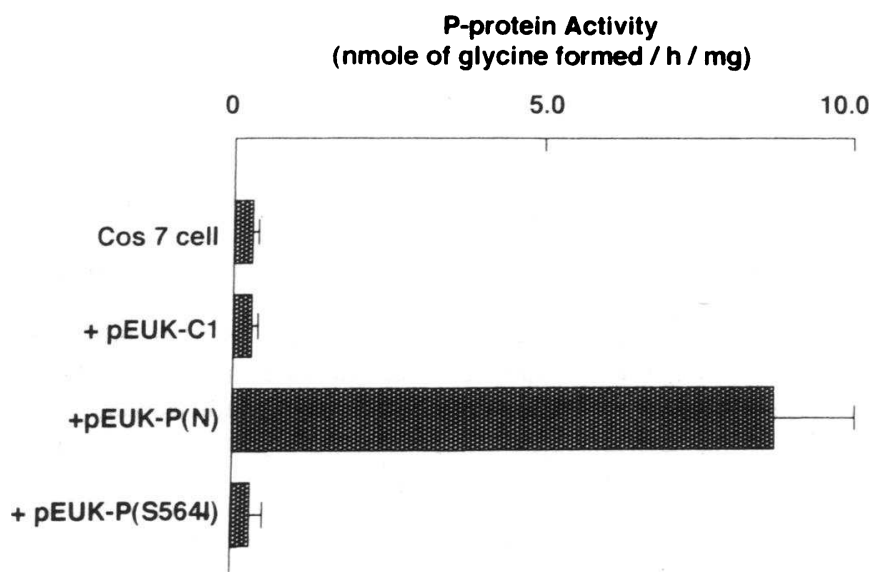

Figure 3. Expression of the normal and mutant $P$ protein cDNA in $\operatorname{COS} 7$ cells. The expression vectors containing entire coding region of normal or mutated $\mathrm{P}$ protein CDNA were transfected into the COS 7 cells. pEUK-P(N) and pEUK-P(S564I) indicate the plasmid with normal and mutant $P$ protein cDNA, respectively. The experiments were performed in triplicate. The values of means \pm SD were indicated.

The prevalence of this mutation in NKH patients. To examine the prevalence of this mutation in Finnish patients with $\mathrm{NKH}$, we prepared genomic DNA samples from nine additional unrelated NKH patients. The genomic DNA was amplified by PCR with the modified primer as shown in Fig. 5. The digestion pattern of the PCR products (Fig. $6 \mathrm{~A}$ ) indicated that there were five homozygotes (Finnish patients 1, 4, 5, 7, and 9) and four heterozygotes $(2,3,8$, and 10$)$ for this mutation in 10 unrelated NKH patients. One patient (patient 6) had no evidence of the S564I P protein allele. The allele frequency was, therefore, $70 \%$ ( 14 out of 20 ). This mutation was not detected in 10 non-Finnish patients with NKH (Fig. $6 \mathrm{~B}$ ) that included one Swedish patient (the non-Finnish patient 8 ).

\section{Discussion}

The nucleotide change from $G$ to $T$ at position 1,691 in the $P$ protein cDNA was a cause of NKH, as evidenced by the following observations. First, this nucleotide change is the only mutation found in the $P$ protein cDNA synthesized from patient 1. Second, this nucleotide change produced a mutant $P$ protein with the amino acid substitution from $\mathrm{Ser}^{564}$ to $\mathrm{Ile}^{564}$, which
A

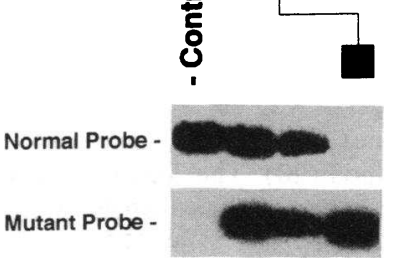

B

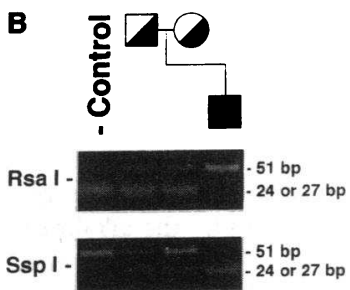

Figure 4. Transmission of the point mutation in the family of the patient 1 . The normal and mutant $P$ protein alleles in family members of the patient 1 were detected by $(A)$ the ASO probe hybridization and $(B)$ the modified PCR method, followed by Rsal and SspI digestions. The digested DNA fragments were size separated by $5.5 \%$ agarose gel electrophoresis and visualized by ethidium bromide staining. 


\section{A Normal allete}

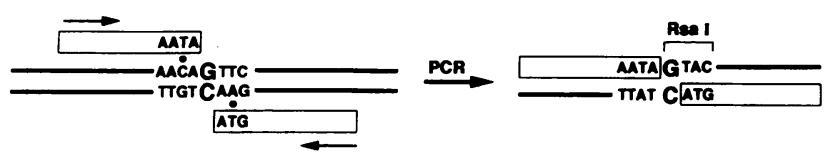

B Mutant allele

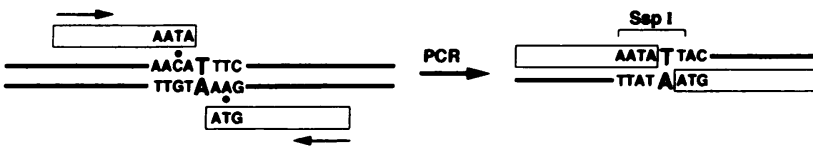

Figure 5. Schema for a new detection method for the S564I mutation. The genomic DNA fragments containing the mutation site were amplified by the modified PCR primers. The dots indicate the positions of nucleotide in PCR primers that were modified to generate the recognition sites for the restriction enzymes in PCR products. The PCR products amplified from the normal allele can be digested by RsaI $(A)$, while the products from the mutant allele can be digested by SspI $(B)$. The bold-faced letters of nucleotide represent the S564I mutation site. Rectangles symbolize the PCR primers.

showed no activity when it was expressed in $\operatorname{COS} 7$ cells. The result of this analysis appeared to be in agreement with the undetectable $P$ protein activity in lymphoblast cells from patient 1 . Finally, the nucleotide change found in $P$ protein cDNA from patient 1 existed in his $P$ protein gene in a homozygous form. The mutation was transmitted from his parents, who were both heterozygous for the mutation.

The S564I mutation was found to be responsible for high incidence of NKH in Finland. In Finnish patients with NKH,

\section{A Finnish}

\section{NKH patient}

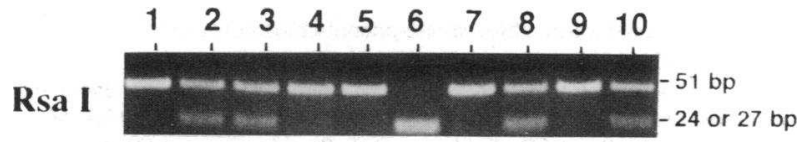

Ssp I

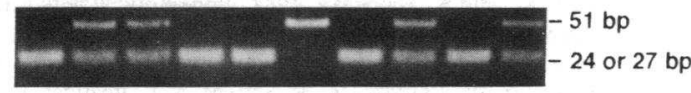

\section{B Non-Finnish}

\section{NKH patient}

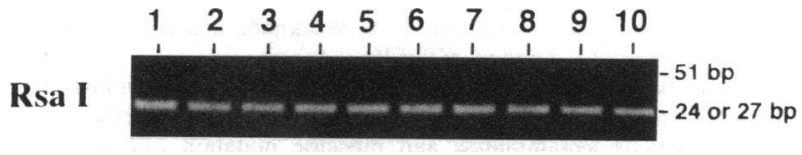

Ssp I

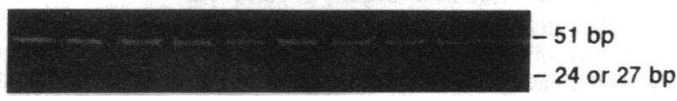

Figure 6. Detection of the point mutation in DNA from Finnish and non-Finnish patients with NKH. The photographs showed the digestion patterns of RsaI and SspI of the PCR products amplified from genomic DNA prepared from $(A) 10$ Finnish patients with NKH and $(B) 10$ non-Finnish patients with NKH.
$70 \%$ ( 14 of 20) of mutant alleles have the S564I mutation. The observation resembles the results of the molecular analysis of the mutation in ornithine- $\delta$-aminotransferase (OAT) deficiency in Finland. The OAT deficiency causes gyrate atrophy of the choroid and retina with high incidence (1:50,000 births) in Finland (22). The L402P mutation is responsible for $85 \%$ of the mutant OAT alleles of the Finnish patients (23). In addition, the L402P mutation was not found in the non-Finnish patients, as was the case of the S564I mutation in the non-Finnish cases of NKH. One Swedish patient with NKH did not have the S564I mutation. This narrow distribution of the S564I as well as that of the L402P mutation confirms the previous view of the genetic isolation of Fins from other population groups (24).

The S564I mutation was found in the homozygous state only in five patients, while four patients were probably compound heterozygotes of the S564I mutant gene and another mutant $P$ protein gene. This heterogeneity was rather unexpected; NKH is clustered mainly in the northern part of Finland, probably because of a subisolation, strongly suggesting that one mutation could account for all the NKH patients, as in the case of aspartylglucosaminuria, another typical example of a Finnish genetic disease (25). The Finnish population expanded from 250,000 in 1700 A.D. to five million at present, by founding and merging the immigrants into a considerable basic population with a probable continuity since the Stone Age (9). The molecular heterogeneity in the Finnish genetic diseases demonstrated by this study and the others may reflect the complexity in the founding of the Finnish population. Additional studies including molecular characterization of the remaining Finnish patients with NKH are in progress, and will further clarify the population genetics of NKH in Finland.

The amino acid ( $\mathrm{Ser}^{564}$ ) altered by the S564I mutation is present in a particular domain of the $\mathrm{P}$ protein. $\mathrm{Ser}^{564}$ is located at the $\mathrm{NH}_{2}$-terminus in a decapeptide ( $\mathrm{Ser}^{564}$ to $\operatorname{Trp}^{573}$ ), which is directly repeated in a nonapeptide from $\operatorname{Ser}^{807}$ to $\operatorname{Trp}^{815}$ (Fig. 7). The amino acid residue that binds to pyridoxal phosphate, a cofactor of $\mathbf{P}$ protein, was determined in chicken $\mathbf{P}$ protein (26), and corresponds to Lys ${ }^{754}$ of the human P protein based on the structural similarity between the chicken and human enzymes. This critical residue resides between the two repetitive structures in $\mathrm{P}$ protein polypeptide (Fig. 7), suggesting that a region from $\operatorname{Ser}^{564}$ to $\operatorname{Trp}^{815}$ is important in $\mathrm{P}$ protein function. In fact, another mutant $P$ protein polypeptide previously identified in a Japanese patient also had a defect in the region from $\mathrm{Ser}^{564}$ to $\mathrm{Trp}^{815}$; $\mathrm{Phe}^{756}$ was deleted by three-base deletion in $\mathrm{P}$ protein gene (5). Because Phe ${ }^{756}$ is located closely to Lys $^{754}$, the binding site of a pyridoxal phosphate, the deletion of Phe ${ }^{756}$ seems likely to interfere with its binding or its function (Fig. 7). Site-directed mutagenesis of $P$ protein might elucidate the structure-function relationship of this protein.

The clinical course of NKH considerably varies among patients, and it will be interesting to compare the severity of the phenotype of mutation(s) present in the patients. The classical presentation is of a very young infant with overwhelming illness, while some patients with relatively mild mental retardation have been reported (1). Some residual overall activity of the GCS was detected in a late-onset patient, and was undetectable in a patient with the neonatal type (27). The S564I mutation could account for the early onset of the overwhelming symptoms, which is common in Finnish patients with NKH (7); when P protein cDNA with the S564I mutation expressed in COS 7 cells, no residual enzyme activity was observed. We 


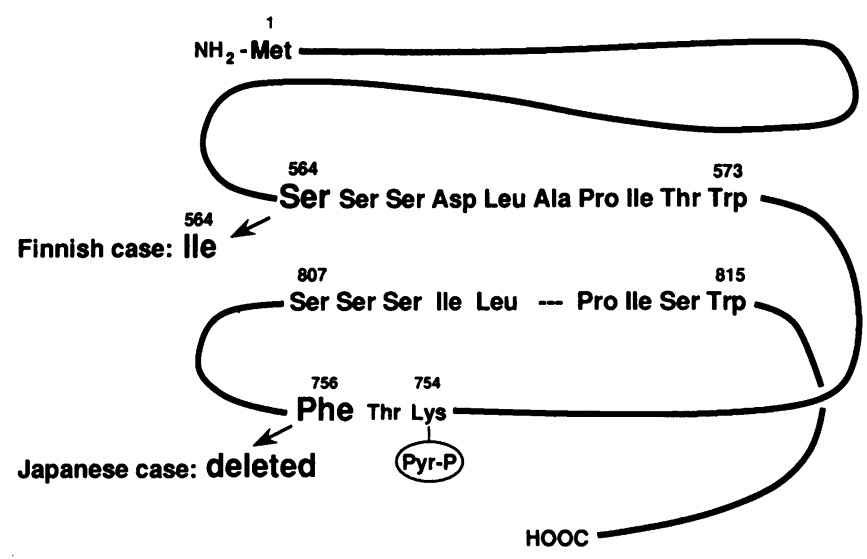

Figure 7. Two mutant $\mathrm{P}$ protein polypeptides identified in patients with NKH. The decapeptide between $\operatorname{Ser}^{564}$ and $\operatorname{Trp}^{573}$ is almost directly repeated in the nonapeptide between $\mathrm{Ser}^{807}$ and $\mathrm{Trp}^{815}$. Phe ${ }^{756}$ was deleted by the three-base deletion identified in a Japanese patient. Pyr-P stands for pyridoxal phosphate. The altered amino acid resulting from the point mutation is shown in a large letter.

infer that homozygotes of this mutation have no residual enzyme activity in vivo and develop the severe clinical symptoms in the early period of life.

A simple and rapid method was developed for the detection of the S564I mutation. This method was originally developed for the detection of mutant Kirsten ras oncogenes in human cancer tissues (28). The original method was designed to detect only the mutant allele by digestion of one restriction enzyme, leaving a possibility of a false negative caused by partial digestion. We improved the original method to allow the detection of both normal and mutant alleles by using two different restriction enzymes (Fig. 7). The result of one digestion pattern is confirmed by the result of the other digestion, which increases the reliability of the assay. Recently, we applied this detection method to the prenatal diagnosis of a fetus at high risk, and successfully diagnosed the case (data not shown).

We have established a direct analysis system of the mutations responsible for NKH using lymphoblasts. Previously, a major difficulty for the molecular analysis of $P$ protein deficiency was to obtain $P$ protein $m R N A$, which is expressed only in the liver, kidney, and brain. In fact, the autopsied liver tissue was used as a source of $P$ protein mRNA in our previous study (5). In this study, we used EBV-transformed lymphoblasts that were recently found to provide an accessible source of $P$ protein enzyme protein and mRNA (11). The establishment of this strategy should facilitate the molecular analysis of the defects in other NKH patients.

\section{Acknowledgments}

We thank Dr. Lennart von Wendt at Children's Castle Hospital, Helsinki, for useful suggestions, and Dr. Riitta Herva at Oulu University Pediatric Pathology for providing us the paraffin-enblocked samples of the Finnish patients with NKH.

This work was supported by grants from the Ministry of Education, Science and Culture, the Ministry of Health and Public Welfare, and the Mitsubishi Foundation, Japan.

\section{References}

1. Nyhan, W. L. 1989. Nonketotic hyperglycinemia. In The Metabolic Basis of Inherited Disease. C. R. Scriver, A. L. Beaudet, W. S. Sly, and D. Valle, editors. McGraw-Hill Inc., New York. 743-753.
2. Tada, K., K. Narisawa, T. Yoshida, K. Yokoyama, H. Nakagawa, K. Tanno, K. Mochizuki, T. Arakawa, T. Yoshida, and G. Kikuchi. 1969. Hyperglycinemia: a defect in glycine cleavage reaction. Tohoku J. Exp. Med. 98:289-296.

3. Kikuchi, G. 1973. The glycine cleavage system: composition, reaction mechanism, physiological significance. Mol. Cell. Biochem. 1:169-187.

4. Tada, K. 1987. Nonketotic hyperglycinemia: clinical and metabolic aspects. Enzyme (Basel). 38:27-35.

5. Kure, S., K. Narisawa, and K. Tada. 1991. Structural and expression analyses of normal and mutant mRNA encoding glycine decarboxylase: three-base deletion in mRNA causes nonketotic hyperglycinemia. Biochem. Biophys. Res. Commun. 174:1176-1182.

6. Kume, A., H. Koyata, T. Sakakibara, Y. Ishiguro, S. Kure, and K. Hiraga. 1991. The glycine cleavage system: molecular cloning of chicken and human glycine decarboxylase cDNA and some characteristics involved in the deduced protein structures. J. Biol. Chem. 266:3323-3329.

7. v. Wendt, L., A. Hirvasniemi, and S. Similä. 1979. Nonketotic hyperglycinemia A genetic study of 13 Finish families. Clin. Genet. 15:411-417.

8. Norio, R., H. Nevanlinna, and J. Perheentupa. 1973. Hereditary diseases in Finland: rare flora in rare soil. Ann. Clin. Res. 5:109-141.

9. Norio, R. 1981. Diseases of Finland and Scandinavia. In Biocultural Aspects of Disease. H. Rothchild and C. F. Chapman, editors. Academic Press Inc., London. 359-415.

10. Kure, S., H. Koyata, A. Kume, Y. Ishiguro, and K. Hiraga. 1991. The glycine cleavage system: the coupled expression of the glycine decarboxylase and the $\mathrm{H}$ protein gene in the chicken. J. Biol. Chem. 266:3330-3334.

11. Kure, S., K. Narisawa, and K. Tada. 1992. Enzymatic diagnosis of nonketotic hyperglycinemia with lymphoblasts. J. Pediatr. 120:95-98.

12. Shibata, D., N. Arheim, and J. Martin. 1988. Detection of human papilloma virus in paraffin-embedded tissue using the polymerase chain reaction. $J$. Exp. Med. 167:225-230.

13. Jinks, D. C., M. Minter, D. Tarver, M. Vanderford, J. F. Hejtmancik, and E. R. B. McCabe. 1989. Molecular genetic diagnosis of sickle cell disease using dried blood specimens on blotters used for newborn screening. Hum. Genet. 81:363-366.

14. Kochi, H., K. Hayasaka, K. Hiraga, and G. Kikuchi. 1979. Reduction of the level of the glycine cleavage system in the rat liver resulting from administration of dipropylacetic acid. Arch. Biochem. Biophys. 198:589-599.

15. Motokawa, Y., and G. Kikuchi. 1969. Glycine metabolism by rat liver mitochondria IV. Isolation and characterization of hydrogen carrier protein as essential factor for glycine metabolism. Arch. Biochem. Biophys. 135:402-409.

16. Okamura-Ikeda, K., K. Fujiwara, and Y. Motokawa. 1987. Mechanism of the glycine cleavage reaction: properties of the reverse reaction catalyzed by $T$ protein. J. Biol. Chem. 262:6746-6749.

17. Bradford, M. 1976. A rapid and sensitive method for the quantitation of microgram quantities of protein utilizing the principle of protein-dye binding. Anal. Biochem. 72:248-256.

18. Chomczynski, P., and N. Sacchi. 1981. Single-step method of RNA isolation by acid guanidium thiocyanate-phenol-chloroform extraction. Anal. Biochem. 162:156-159.

19. Winship, P. R. 1989. An improved method for directly sequencing PCRamplified material using dimethylsulfoxide. Nucleic Acids Res. 17:1266.

20. Reed, K. C., and D. A. Mann. 1985. Rapid transfer of DNA from agarose gels to nylon membranes. Nucleic Acids Res. 13:7207-7221.

21. Tada, K., and K. Hayasaka. 1987. Nonketotic hyperglycinemia: clinical and biochemical aspects. Eur. J. Pediatr. 146:221-227.

22. Valle, D., and O. Simell. 1989. The hyperornithinemias. In The Methobolic Basis of Inherited Disease. C. R. Scriver, A. L. Beaudet, W. S. Sly, and D. Valle, editors. McGraw-Hill Inc., New York. 599-627.

23. Mitchell, G., L. C. Brody, I. Sipla, J. E. Looney, C. Wong, J. F. Engelhart, A. S. Patel, G. Steel, C. Obie, et al. 1989. At least two alleles of ornithine $\delta$-aminotransferase cause gyrate atrophy of the choroid and retina in Finns. Proc. Natl. Acad. Sci. USA. 86:197-201.

24. Nevanlinna, H. R. 1980. Rare hereditary diseases and markers in Finland: an introduction. In Population Structure and Genetic Disorders. A. W. Eriksson, H. R. Forsius, H. R. Nevanlinna, P. L. Workman, and R. K. Norio. editors. Academic Press Inc., London. 569-576.

25. Ikonen, E., M. Baumann, K. Grön, A.-C. Syväven, N. Enomaa, R. Halila, P. Aula, and L. Peltonen. 1991. Aspartylglucosaminuria: cDNA-encoding human asparthylglucosaminidase and missense mutation causing the disease. EMBO (Eur. Mol. Biol. Organ.) J. 10:51-58.

26. Fujiwara, K., K. Okamura-Ikeda, and Y. Motokawa. 1987. Amino acid sequence of the phosphopyridoxyl peptide from $P$ protein of the chicken liver glycine cleavage system. Biochem. Biophys. Res. Commun. 149:621-627.

27. Hayasaka, K., K. Tada, N. Fueki, Y. Nakamura, W. Nyhan, K. Schmidt, S. Packman, M. R. Seashore, E. Haan, and D. M. Danks. 1987. Nonketotic hyperglycinemia: analyses of glycine cleavage system in typical and atypical cases. J. Pediatr. 110:873-877.

28. Haliassos, A., J. C. Chomel, L. Tesson, M. Baudis, J. Kruh, J. C. Kaplan, and A. Kitzis. 1989. Modification of enzymatically amplified DNA for the detection of point mutations. Nucleic Acids Res. 17:3606. 